\title{
VÝVOJ LEDOVCOVÝCH SEDIMENTŮ NA KONTAKTU S ŽULOVSKÝM MASIVEM VE ŠTACHLOVICÍCH U VIDNAVY
}

\author{
Development of glacigenic sediments on contact with Žulová batholith in Štachlovice \\ by Vidnava town
}

\author{
Martin Hanáček', Zbyněk Engel ${ }^{2}$, Barbora Procházková \\ 'Ústav geologických věd, Prírodovědecká fakulta, Masarykova univerzita, Kotlářská 267/2, 61137 Brno; \\ e-mail: HanacekM@seznam.cz \\ ${ }^{2}$ Katedra fyzické geografie a geoekologie, Přrrodovědecká fakulta, Univerzita Karlova, Albertov 6, 12843 Praha; \\ e-mail:zbynek.engel@natur.cuni.cz; baara.prochazkova@gmail.com
}

(14-22 Jeseník)

Key words: Pleistocene, continental glaciation, glacitectonite, subglacial cavity infill, supraglacial melt-out till, terminoglacial stream sediments, drumlin, Žulová Upland

\begin{abstract}
The Žulová Upland is composed of granitoids of the Žulová batholith with relicts of Pleistocene (Elsterian) continental glaciation sediments. The investigated outcrop represents development of glacigenic sediments on rugged topography of the Žulová Upland. Investigated locality is situated on a hill located on the northern margin of the Žulová Upland. It is located near Štachlovice, local part of the Vidnava town. The exposed part of the hilltop reveals a preglacial basement covered by glacigenic sediments. The facies analysis and gravel petrology analysis of clasts with fraction 16-64 $\mathrm{mm}$ in b-axis were undertaken on the walls of the outcrop. The Georadar (GPR, Ground penetrating radar) was used to investigate the sedimentary landform and its relation to the basement. The granitoid basement is in places formed by elevations covered by glacigenic sediments. The height of elevation reaches $350 \mathrm{~cm}$ in outcrop, or ca $\sim 400 \mathrm{~cm}$ according to the GPR survey. The glacitectonite, formed on the gentle side of elevation, is composed of angular blocks of granitoids of the Z̈ulová batholith, diamicton, sand, gravel and deformed glacifluvial sand. The glacitectonite was deposited during the advancement of the continental glacier. The original subglacial cavity is enclosed by a steep side of the elevation. This cavity is filled by foreset body composed of stratified sand and gravel and nonstratified gravelly sand, gravel and diamicton. The cavity was filled by high-density turbidity currents and debris flow in subaqueous-subaerial environment. The infill of the cavity reaches $\sim 400 \mathrm{~cm}$ in thickness according to the GPR survey. The cavity was filled during deglaciation in subglacial environment. The glacitectonite underlies the diamicton (supraglacial till) that was deposited as a debris flow during the retreat of the continental glacier. Unsorted gravel overlaps with erosional base the infill of the cavity, this gravel has a huge extent according to the GPR survey. This sediment represents the environment of terminoglacial stream. Gravel material of all types of glacigenic sediments is mainly composed of rocks from the Rychleby Mts. (amphibolites, Gieraltow orthogneiss, other diverse gneisses, quartzites, mica schist), quartz, and Nordic and Polish rocks. Subglacial sediments contain clasts of amphibolites ( 40\%), on the other hand supraglacial and terminoglacial sediments are more polymict. Dominant subrounded shape ( 60-70\%) of clasts and composition of this material indicates its origin in preglacial fluvial sediments. These fluvial sediments were deposited by river flowing from the Rychleby Mts. towards their northern foreland. The locality represents preglacial elevation of bedrock, which was glacitectonically deformed during the glaciation. Lots of different types of sediments (sub-, supra-, and terminoglacial) were deposited around the elevation during deglaciation period. The elevation was completely buried by these sediments. Deposition of these sediments was related with morphology of the elevation of bedrock. Formation of these sediments took place in environment analogous to environment of part bedrock/part till drumlin (Stokes et al. 2011).
\end{abstract}

Úvod

Vztah sedimentů pleistocenního pevninského zalednění a preglaciálního podloží má $\mathrm{v}$ oblasti Rychlebských hor a Zlatohorské vrchoviny trojí známý charakter. Prvním typem jsou výplně velkých, morfologicky podmíněných depresí v pevném skalním podloží, ve kterých se akumulovaly až $50 \mathrm{~m}$ mocné sub-, termino- a proglaciální glacifluviální a deltové sedimenty (lokality Supíkovice, Kolnovice a Písečná; Žáček et al. 2004; Hanáček et al. 2015). Druhý typ představuje ploché, kaolinicky zvětralé podloží, na němž se $\mathrm{v}$ termino- až proglaciálním prostředí uložily $\sim 10 \mathrm{~m}$ mocné glacifluviální a glacilakustrinní sedimenty (lokalita Stará kaolínová jáma u Vidnavy; Gába 1992). Třetím typem jsou mírné elevace (drumliny) nezpevněného, částečně plastického podloží, pokrytého subglaciálními a supraglaciálními tilly a glacifluviálními písky s proměn- livou mocností (lokality Hrouda u Velké Kraše a Písečník u Javorníku; Pecina et al. 2005; Hanáček et al. 2013).

V Žulovské pahorkatině se ledovcové sedimenty zachovaly jen místy (Prosová 1981; Žáček et al. 2004). Jedná se o subglaciální tilly, glacifluviální a glacilakustrinní sedimenty, které jsou většinou známy jen z povrchového mapování, kopaných sond nebo vrtů. Těžbou byly zastiženy v kaolínových jámách a drobných pískovnách jv. od Vidnavy a dále v několika malých odkryvech u Horních Heřmanic, Bukové, Velké Kraše, Žulové a Skorošic. Z těchto odkryvů bylo bliže studováno jen hliniště se subglaciálními tilly ve Skorošicích (Gába 1972; Prosová 1981) a Stará kaolínová jáma na Vidnavsku (Gába 1992). Ostatní odkryvy zanikly bez podrobnějš́ího prozkoumání. Podle nejnovějších výzkumů náleží ledovcové sedimenty Žulovské pahorkatiny elsterskému zalednění (Nývlt et al. 2011). 

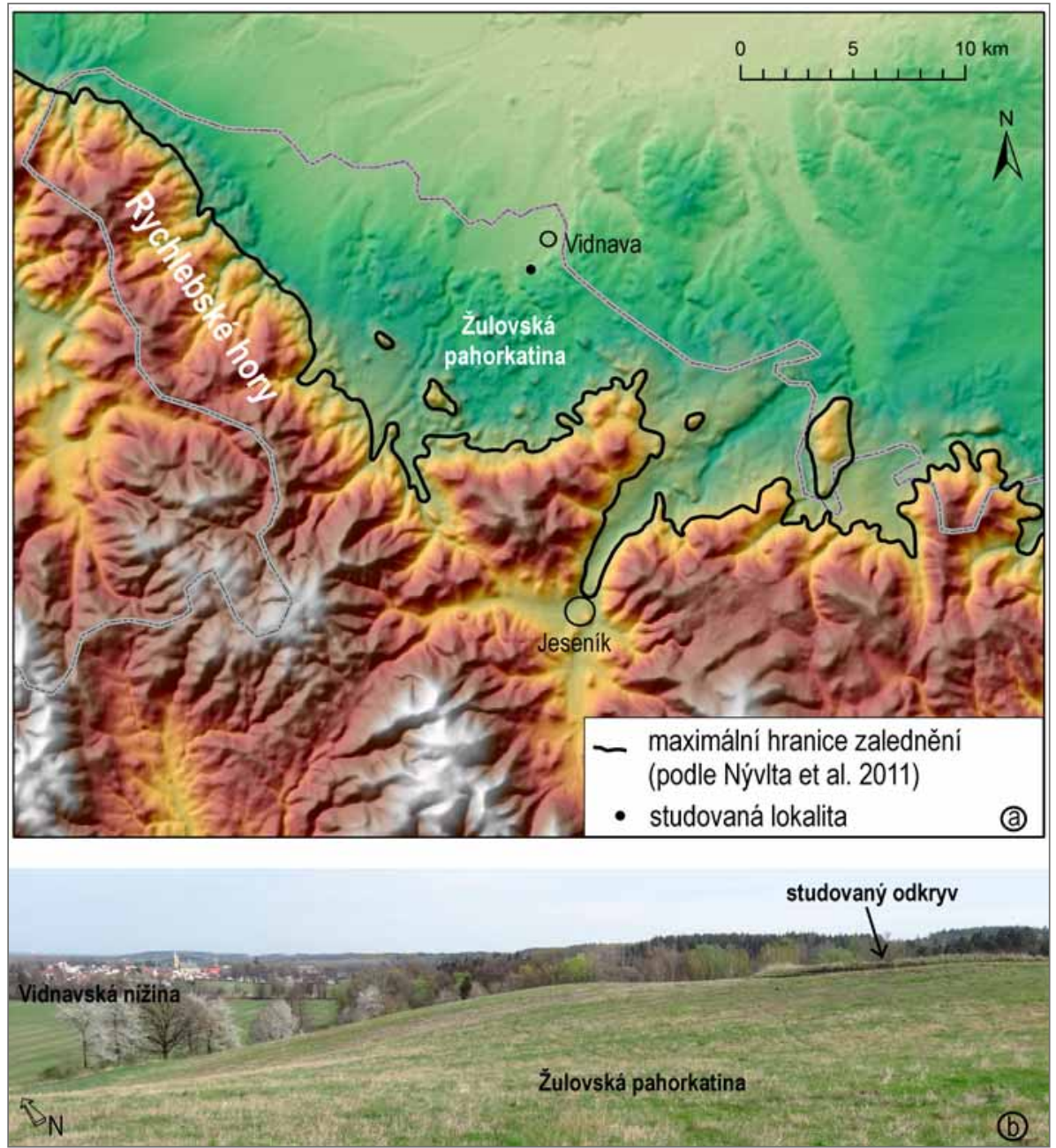

Obr. 1: Poloha a morfologie terénu v oblasti lokality.

Fig. 1: Localization and geomorphology of studied site.

V tomto př́spěvku je popsán opuštěný odkryv u Štachlovic na Vidnavsku, který je rovněž novou lokalitou ukazující kontakt ledovcových sedimentůs s preglaciálním podložím (žulovským masivem).

\section{Lokalita}

Studovaný odkryv se nachází $250 \mathrm{~m}$ sz. od osady Štachlovice a $1500 \mathrm{~m}$ jz. od náměstí ve Vidnavě (obr. 1a). Má okrouhlý tvar o velikosti $60 \times 60 \mathrm{~m}$ a hloubce max. $4 \mathrm{~m}$ (obr. 4b). Lokalita se nachází na exponované, morfologicky výrazné severní hraně Žulovské pahorkatiny. Leží na temeni bezejmenného oblého pahorku o nadmořské výšce $275 \mathrm{~m}$, který severním směrem prudce upadá do Vidnavské nížiny, jejíž přilehlá část má nadmořskou výšku $240 \mathrm{~m}$ (obr. 1b). Východní a jihovýchodní svahy jsou rovněž př́kré. V nadmořské výšce $260 \mathrm{~m}$ na ně navazuje plošší reliéf. Směrem na jihozápad pahorek plynule přechází do plochého až mírně zvlněného terénu Žulovské pahorkatiny, který se jižním směrem pozvolna zvedá do nadmořské výšky $\sim 300 \mathrm{~m}$. Oblast lokality je budována biotitickým granitem až granodioritem žulovského masivu, překrytým stř̌edněpleistocenními glacifluviálními písky až písčitými štěrky (Žáček et al. 2004).

\section{Metodika}

V severní a západní stěně odkryvu byly začištěny profily A-C a v krátkém úseku východní stěny profil D (obr. 2). Horniny preglaciálního podloží byly popsány jen na základě makroskopického pozorování. V sedimentární akumulaci byly rozlišeny členy $1-5$, které byly vymezeny na základě texturních a strukturních znaků a rozhraní těles. Ve dvou členech byly vymezeny jednotky, odrážející faciální variabilitu uvnitř členu. Diamiktony byly granulometricky vyhodnoceny sítováním za mokra na normalizovaných sítech sedimentologické laboratoře Ústavu geologických věd Přírodovědecké fakulty $\mathrm{MU}$ a klasifikovány podle Hambreyho - Glassera (2012). $\mathrm{K}$ genetické klasifikaci tillů byla použita původní anglická terminologie, zavedená do české literatury Růžičkovou et al. (2003). Vzorky pro valounové analýzy byly odebrány lopatkou a normalizovanými síty. Vybraná frakce 16-64 mm v b-ose umožňuje dobrou makroskopickou petrografickou určitelnost klastůa a je pro zkoumané sedimenty reprezentativní. Počty klastů v analýzách se pohybují mezi 496 a 689 (celkem pět analýz s 2867 klasty). Zaoblení klastů bylo vyhodnoceno podle Powerse (1953). Analýza paleoproudění byla provedena měřením spádnic zvrstvení a spádnic ploch definovaných a-, b-osami u velkých klastů.

Pro georadarové měření byla použita nestíněná anténa s vysílací frekvencí $50 \mathrm{MHz}$ a elektronická jednotka Mala RAMAC CU-II (MALA GeoScience, 2005). Využití nízkofrekvenční antény umožňuje vy̌̌ší hloubkový dosah vysílaného signálu. Délka časového okna měření byla nastavena na 437 ns, krok měření na $0,05 \mathrm{~s}$. Přesná pozice georadarových profilů byla zaznamenávána pomocí GPS Garmin GPSMAP 60CXs s chybou v přesnosti měření $<4 \mathrm{~m}$. Naměřná GPR data byla zpracována a interpretována s využitím softwaru Reflex ver. 7.5. Použitá hodnota $80 \mathrm{~m} / \mu$ s odpovídá rychlosti šiření elektromagnetického signálu, zjištěné Cassidym et al. (2003) pro štěrky a štěrkové písky glacifluviálního prostředí. Data byla filtrována pomocí statické korekce, nízkofrekvenčního filtru Dewow a filtru Manual Gain Y. 


\section{Výsledky}

Profil A (obr. 2, 3a)

Profil byl začištěn v severní stěně odkryvu. Zachycuje skalní podloží žulovského masivu, zcela pohřbené ledovcovými sedimenty. Skalní výčnělek je tvořen šedým drobno- až střednozrnným biotitickým granitoidem, velmi silně zvětralým. Odkrytá část dosahuje výšky min. $350 \mathrm{~cm}$ a délky $800 \mathrm{~cm}$ (obr. 3 b, c). Povrch výčnělku nese široké deprese a menší žlábky, př́povrchová zóna je protkána převážně subhorizontálními puklinami (bílé šipky na obrázku 3c). Sedimenty obklopující výčnělek byly rozděleny do čtyř členů.

\section{Člen 1 (obr. 3d, e)}

Tento člen dosahuje mocnosti min. $200 \mathrm{~cm}$, avšak báze nebyla dosažena. Je tvořen angulárními bloky žulovského granitoidu, diamiktony, štěrky a písky. Velikost bloků se pohybuje mezi několika $\mathrm{cm}$ až $1 \mathrm{~m}$. Hornina bloků je silně zvětralá. Mezihmotu tvoří laminovaný i masivní štěrkovitý písek, štěrk a písčitý diamikton bohatý na klasty, místy i drť žulovského granitoidu. Zvrstvené sedimenty vyplňují především větší prostory mezi bloky. Směrem do nadloží ubývá bloků a přibývá mezihmoty. Vyskytují se zdeformované i nedeformované kry štěrkovitého písku o velikosti $100-200$ cm se zachovalým pozitivně gradačním a šikmým zvrstvením a dále malé útržky stejného písku o velikosti do $20 \mathrm{~cm}$ (bílé šipky v obrázku 3d). Štěrkové klasty tvoří hlavně amfibolity+metagabra ( 43\%) a křemen ( 17 \%). Další místní horniny (gierałtowská rula, kvarcity, světlé granitoidy, různé ruly, svory a jiné metamorfity) a dále nordické+polské a neurčené horniny nepřesahují svými jednotlivými podíly $10 \%$ materiálu (obr. $4 \mathrm{~d}$ ).
Člen 2 (obr. 3b)

Jedná se o sedimentární akumulaci mocnou min. $300 \mathrm{~cm}$ a přiléhající k západní svislé stěně granitoidního výčnělku. Laterálně ji lze rozdělit na dvě jednotky. Od výčnělku vzdálenější jednotka $2 a$ je tvořena hlavně písčitým štěrkem $\mathrm{s}$ velmi hojnými klasty o velikosti $\mathrm{v}$ prvních $\mathrm{cm}$ a s prríměsí klastů do $20 \mathrm{~cm}$ v a-ose. Podřízeně se objevují polohy štěrku s hojnými klasty nad $10 \mathrm{~cm} \mathrm{v}$ a-ose (max. $32 \mathrm{~cm}$ ) mající podpůrnou strukturu klastů i mezihmoty. V této části je zřetelné šikmé zvrstvení velké škály (ukloněné zvrstvení). Ploché klasty upadají ve směru i proti směru upadání vrstev. Většina těchto klastů je orientována k SV a JV (obr. 4c) a ukloněna pod úhly v rozmezí 5-52. K výčnělku bližší jednotka $2 b$ se vyznačuje zřetelným nárůstem podílu klastů dlouhých $10-30 \mathrm{~cm}$ v a-ose. Vytřídění sedimentů jednotky $2 \mathrm{~b}$ se zhoršuje směrem $\mathrm{k}$ výčnělku. Při kontaktu s jednotkou 2a se jedná o štěrky, ale u svislé stěny výčnělku jde i o přechodný diamikton bohatý na klasty. Sedimenty se stávají masivními s častou subvertikální orientací velkých klastů (56\% klastů upadá pod úhly $10-45^{\circ}$, $44 \%$ pod úhly $45-90^{\circ}$ ). Velké ploché klasty jsou orientovány hlavně na J, méně na JV a JZ (obr. 4c). Ve spodní části jednotky $2 \mathrm{~b}$ převládají klasty amfibolitů+metagaber $(\sim 38 \%)$ a křemene $(\sim 14 \%)$. Ostatní určitelné petrotypy jsou zastoupeny každý do $10 \%$. Ve svrchní části jednotky 2 b se vyrovnávají podíly klastů amfibolitů+metagaber $(\sim 30 \%)$ s klasty křemene $(\sim 22 \%)$ a rovněž roste podíl gierałtowské ruly $(\sim 14 \%)$. Jednotlivé podíly ostatních hornin nepřekračují $10 \%$ (obr $4 \mathrm{~d}$ ).

\section{Člen 3 (obr. 3d, e)}

Tento člen nasedá se zvlněnou ostrou bází na člen 1 . Má proměnlivou mocnost v rozmezí $20-90 \mathrm{~cm}$. Je tvořen písčitým diamiktonem bohatým na klasty až písčitým štěr
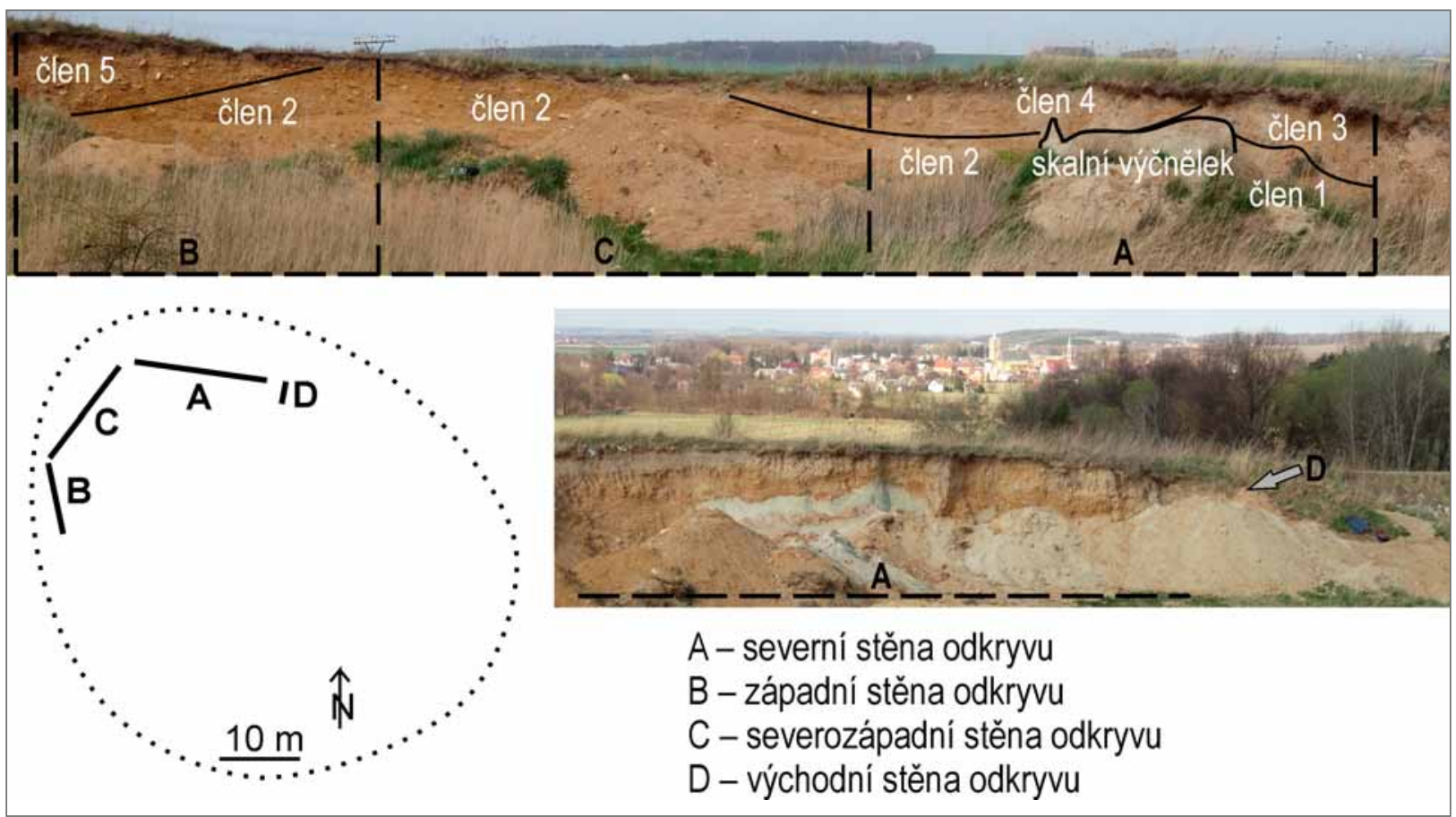

Obr. 2: Profily ve štachlovickém odkryvu.

Fig. 2: Studied sections in the Štachlovice outcrop. 
kem. Velmi hojné jsou klasty do $5 \mathrm{~cm}$, méně kolem $10 \mathrm{~cm}$ $\mathrm{v}$ a-ose. Většina klastů je svými a-osami a plochami definovanými a-, b-osami uspořádána paralelně s průběhem báze. Četnost štěrkových klastů je laterálně proměnlivá. $\mathrm{V}$ mezihmotě jasně dominuje písek. Hlavními složkami štěrku jsou křemen $(\sim 23 \%)$, gierałtowská rula $(\sim 22 \%)$ a amfibolity+metagabra ( $20 \%)$. Nordika+polské horniny představují $11 \%$ materiálu. Z ostatních petrotypů žádný nedosahuje $10 \%$ (obr $4 \mathrm{~d}$ ).

\section{Člen 4 (obr. 2, obr. 3b, c)}

Nejvyšší člen profilu A nasedá s mělkou výmolovou bází na člen 2, dále na přilehlou část granitoidního výčnělku a člen 3. Představuje dvě tělesa. První, mělce zahloubené do členu 2 a přiléhající k západnímu okraji granitoidního výčnělku, je v prríčném řezu $~ 950 \mathrm{~cm}$ široké a vyplněné sedimenty mocnými min. $80 \mathrm{~cm}$ (původní mocnost mohla být zredukována erozí). Druhé těleso, mocné min. $60 \mathrm{~cm}$, vyplňuje depresi v povrchu skalního výčnělku, kde rovněž spočívá nad reliktem členu 3 (černá šipka v obrázku 3c). Oproti členu 2 je člen 4 zřetelně jemnozrnnější. Výplň tvoří laminované až tence zvrstvené štěrkovité hrubozrnné písky s hojným štěrčíkem a klasty do $1 \mathrm{~cm}$ velikosti. Střídají se písčitější a štěrkovitější polohy. Při západním okraji tělesa nad členem 2 se vkládají polohy s hojnými klasty do $10 \mathrm{~cm}$ $\mathrm{v}$ a-ose, ukloněnými proti upadání vrstev. Zvrstvení je orientováno převážně na ZSZ, pod úhly $3-7^{\circ}$ (obr. 4c).

\section{Profil B (obr. 2)}

$\mathrm{V}$ západní stěně situovaný profil odhaluje dvě sedimentární tělesa, oddělená diskordantním povrchem (obr. 3g, ch). Spodní člen představuje pokračování členu 2 z profilu A. Nad diskordantním povrchem pak leží další člen 5 .

\section{Člen 2 (obr. 3g, ch)}

Tento člen představuje těleso s šikmým zvrstvením velké škály (ukloněným zvrstvením). Faciálně jej lze rozdělit do tří jednotek. Ve stěně nejníže spočívá jednotka 2c. Dosahuje mocnosti min. $160 \mathrm{~cm}$, přičemž její báze nebyla zastižena. Jednotka začíná nezřetelně šikmo zvrstvenými písčitými štěrky o mocnosti min. $40 \mathrm{~cm}$. V nich jsou $1-3 \mathrm{~cm}$ mocné vrstvy bohaté na klasty max. $8 \mathrm{~cm}$ velké, které se střídají s vrstvami složenými $\mathrm{z}$ hrubozrnného písku, štěrčíku a klastů do $1 \mathrm{~cm}$ velikosti. Následuje $120 \mathrm{~cm}$ mocný set laminovaných až tence zvrstvených střednozrnných a hrubozrnných písků, s podřízenými polohami štěrčíku (obr. 3 h). V celém setu jsou rozptýleny klasty do $10 \mathrm{~cm}$ velikosti. Zvrstvení jednotky 2 c je pod úhly $17-30^{\circ}$ ukloněno k SV (obr. 4c). Nadložní jednotka 2d je oproti jednotce 2c hrubozrnnější (převládá hrubozrnný písek a štěrčík). Vyznačuje se neprůběžným a nezřetelným zvrstvením. Přibývá klastů až $\sim 10 \mathrm{~cm}$ velkých, které jsou volně rozptýleny, ale i seřazeny do samostatných poloh. Jednotka dosahuje mocnosti $120 \mathrm{~cm}$. Nejsvrchnější část zaujímá jednotka 2e mocná min. $200 \mathrm{~cm}$. Je opět hrubozrnnější než podložní jednotka. Převládá štěrčík, hrubozrnný až velmi hrubozrnný písek a klasty v prvních $\mathrm{cm}$ velikosti. Velmi hojně se vyskytují klasty dlouhé $10-20 \mathrm{~cm}$, výjimečně $30 \mathrm{~cm}$ v a-ose.
Zvrstvení není prrítomno, nebo jen místy nezřetelně, ale velké ploché klasty jsou orientovány souhlasně s úklonem báze jednotky 2e.

\section{Člen 5 (obr. $3 g, c h)$}

Svrchní člen profilu B nasedá s ostrou, výmolovou erozní bází na člen 2. Převážně se jedná o špatně vytříděný hrubozrnný písčitý štěrk s klasty hojně do $10 \mathrm{~cm}$ v a-ose. Po straně výmolu se jedná až o písčitý diamikton bohatý na klasty (šipka v obrázku $3 \mathrm{ch}$ ). Zde jsou rovněž vtroušeny klasty do $25 \mathrm{~cm}$ v a-ose. Velké ploché klasty jsou nejčastěji orientovány souhlasně s průběhem báze, ale vyskytuje se i chaotická orientace, včetně subvertikální. Ve svrchní části výplně se objevuje nezřetelné šikmé i subhorizontální zvrstvení. Na složení štěrkových klastů se podílí hlavně křemen ( 26\%). Ostatní složky jsou méně početné: gierałtowská rula $(\sim 14 \%)$, nordické+polské horniny $(\sim 11 \%)$ a amfibolit+metagabro ( 11\%). Jednotlivé podíly dalších hornin nedosahují $10 \%$ (obr. 4d).

\section{Profily C a D}

V těchto profilech nebyly začištěny rozsáhlejší stěny (obr. 2). Profil C je tvořen sedimenty, které představují člen 2 , konkrétně laterální pokračování jednotky 2e z profilu B. Velké ploché klasty v profilu C upadají pod úhly $4-40^{\circ}$ převážně $\mathrm{k} \mathrm{V}$, méně často $\mathrm{kJV}$ a SV (obr. 4c). Profil D odhaluje sedimenty zcela odpovídající členu $1 \mathrm{v}$ profilu A (obr. 3f).

Zaoblení štěrkových klastů vykazuje ve všech členech stejné trendy. Převládají suboválné klasty ( 60-70\%). Ostatní kategorie zaoblení mají podstatně nižší podíly: subangulární 15-17\%, oválné 10-16\%, angulární 3-4\% a dokonale oválné $0,5-2 \%$. Velmi angulární stupeň nebyl pozorován. Ohlazy a exarační rýhy se na povrchu klastů vyskytují vzácně, rovněž tak projevy eolizace.

\section{Georadarový průzkum}

Podél odkryvu byly provedeny dva georadarové řezy: podél severní stěny (nad profilem A) řez $\mathrm{P} 7$ a podél západní stěny (nad profilem $\mathrm{B}$ ) řez $\mathrm{P} 8$, viz obrázky $4 \mathrm{a}, \mathrm{b}$. V radargramu P7 jsou nejníže vidět mírně konvexní reflexy (bílé šipky v obrázku 4a) a nad nimi série šikmých reflexů velké škály, ukloněných $\mathrm{k}$ V. V úseku procházejícím nad svislým kontaktem členu 2 a skalním výčnělkem (31.39. m) šikmé reflexy náhle mizí. Objevuje se jeden silný, mírně zvlněný reflex, upadající proti orientaci šikmých reflexů (bílá šipka vpravo v radargramu P7 na obrázku 4a). V radargramu $\mathrm{P} 8$ se v úseku nad profily $\mathrm{B}$ a C objevují dva silné reflexy. Spodní je mírně zvlněný, subhorizontální (bílé šipky v obrázku 4a). Svrchní reflex je ukloněný k J a probíhá až skoro k jižnímu konci radargramu P8 (šedá šipka v obrázku 4a). V severní části radargramu P8 se objevují šikmé reflexy velké škály upadající na S.

\section{Diskuze \\ Interpretace členů sedimentární akumulace}

Granitoidní výčnělek představuje elevaci preglaciálního reliéfu žulovského masivu. Geneze okolních sedi- 

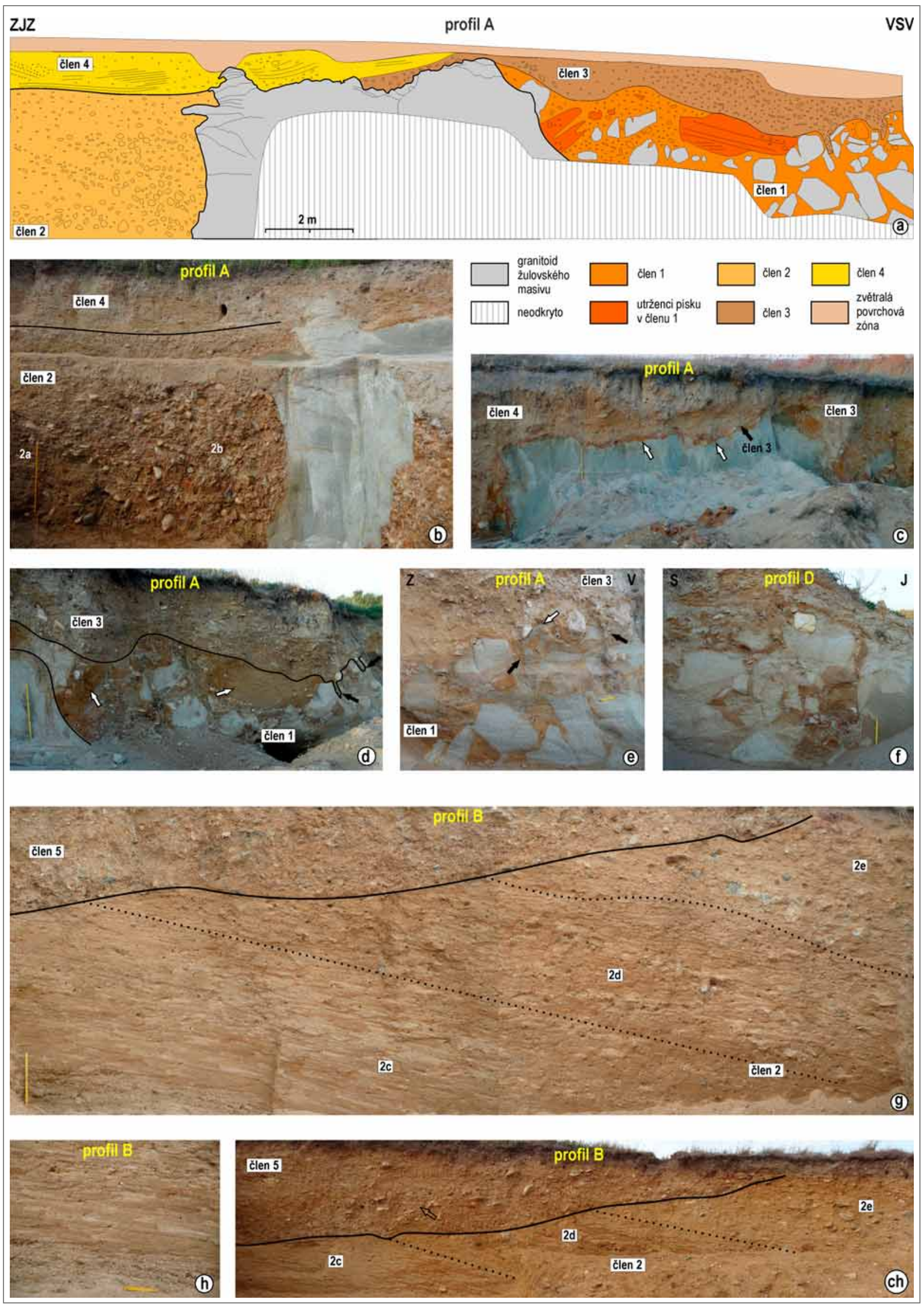

Obr. 3: Sedimenty profilů A, B a D. Délka měřítka: $3 b-100 \mathrm{~cm} ; 3 \mathrm{c}, 3 \mathrm{~d}-60 \mathrm{~cm}, 3 \mathrm{e}, \mathrm{f}, \mathrm{h}-20 \mathrm{~cm} ; 3 \mathrm{~g}-40 \mathrm{~cm}$. Výška profilu na obrázku $3 \mathrm{ch}-200 \mathrm{~cm}$.

Fig. 3: Sediments of A-section, B-section and D-section. Scale lenght: $3 b-100 \mathrm{~cm} ; 3 \mathrm{c}, 3 \mathrm{~d}-60 \mathrm{~cm}, 3 \mathrm{e}, \mathrm{f}, \mathrm{h}-20 \mathrm{~cm} ; 3 \mathrm{~g}-40 \mathrm{~cm}$. Section height in figure $3 \mathrm{ch}-200 \mathrm{~cm}$. 


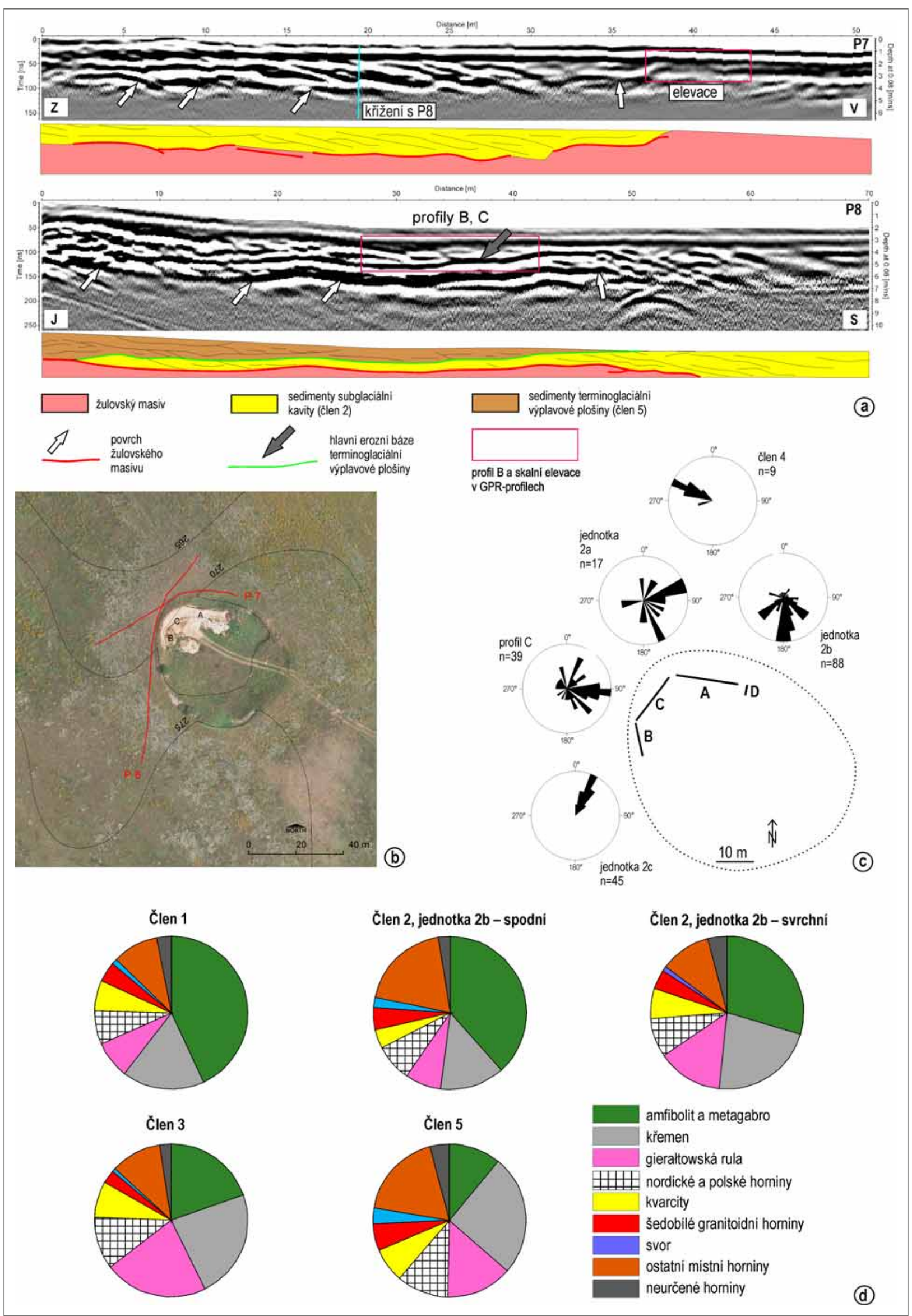

Obr. 4: a, b -Georadarové profily; c - orientace zvrstvení a klastů; d - valounové analýzy.

Fig. 4: a, b - Ground penetrating radar sections; $\mathrm{c}$ - directions of stratification and directions blade clasts; $\mathrm{d}$ - clast petrology analysis diagrams. 
mentů je vyjma členu 5 přímo spjata právě s prrítomností této elevace a na ni navazující terénní deprese.

Člen 1 lze interpretovat jako glacitektonit (Evans et al. 2006). Postupující ledovec deformoval svahy podložní elevace a odděloval z granitoidního masivu jednotlivé bloky. Rozpad masivu byl usnadněn silným povrchovým rozpukáním a blokovitou odlučností granitoidu, které byly intenzivně podporovány periglaciálním klimatem ještě před prrímým zásahem ledovce. Jednotlivé menší fragmenty granitoidu vznikaly rozpadem původně větších bloků, protože na profilech A a D lze vysledovat původní prostorové spojitosti zcela nebo jen částečně oddělených kusů (obr. 3e, f). Zachovalost prostorových vazeb směrem od báze nahoru vyznívá (obr. 3e). Jen částečně rozpadlé kusy lze označit jako glacitektonickou brekcii (Croot Sims 1996). Prostorové vztahy mezi oddělenými kusy granitoidu dokládají proces drcení během formování glacitektonitu. Kromě skalního podkladu deformoval ledovec i štěrkopískové sedimenty, které nejspíš vznikly v sub, termino- nebo proglaciální pozici během postupu nebo stagnace ledovce a dalším postupem ledovce byly v částečně zmrzlém stavu erodovány a deformovány. Fragmenty skalního podloží i útržky starších sedimentů byly smíchány s ostatním detritem transportovaným v subglaciální zóně. Genetickou vazbu glacitektonitu k podložní elevaci naznačuje jeho omezený výskyt pouze na pozvolné straně elevace, která byla náběžná vưči předpokládanému severojižnímu směru postupu ledovce (Hanáček 2014).

Člen 2 tvoří jedno těleso, které lze kvůli velkoškálovému šikmému zvrstvení označit za foreset (obr. 2). Stavbu odpovídající foresetu lze pozorovat i na radargramech, v nichž velkoškálovému šikmému zvrstvení odpovídá sada šikmých reflexů velké škály (obr. 4a). Vztah tělesa ke granitoidní elevaci dokazuje, že těleso vyplňuje depresi, aspoň částečně zahloubenou do skalního podkladu. Lokální omezení foresetu je zřejmé z radargramů (obr. 4a). Foreset

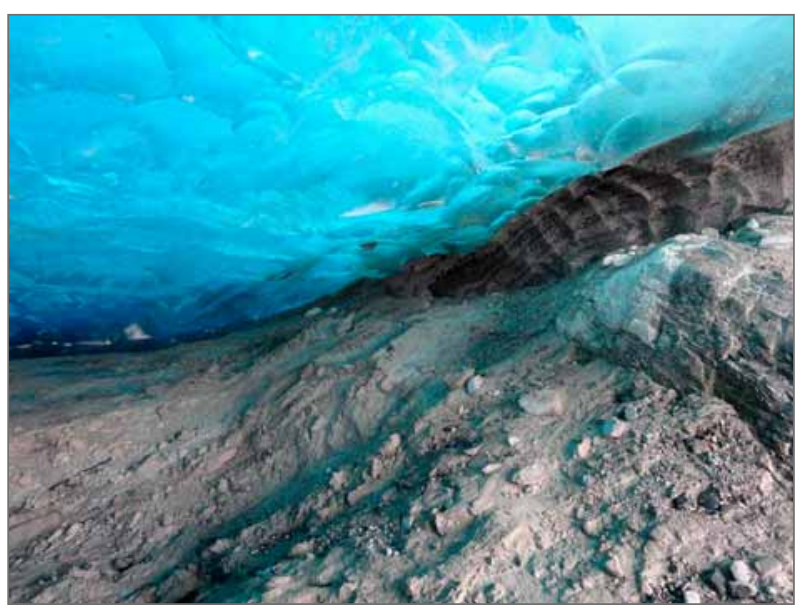

Obr. 5: Subglaciální kavita při čele ledovce Nordenskiöldbreen na Svalbardu. Na členitém skalním podloží se ve formě úlomkotoků akumulují supraglaciální melt-out tilly. Možný moderní ekvivalent k jednotce $2 \mathrm{~b}$ členu 2.

Fig. 5: Subglacial cavity close to the front of the Nordenskiöldbreen glacier, Svalbard. Supraglacial melt-out till (debris flow) accumulates on the bedrock with rugged topography. Possible modern analogue to unit $2 \mathrm{~b}$ of member 2 . je jasně omezen reflexy označenými na řezech P7 a P8 bílými šipkami. Tyto reflexy jsou interpretovány jako povrch preglaciálního granitoidního podloží. Důvodem k tomuto výkladu je častý konvexní tvar těchto reflexů a dále určitá podobnost mezi orientací reflexu na 31.-39. m vůči sadě velkoškálových šikmých reflexů v radargramu P7 a svislým okrajem elevace oproti foresetu v profilu A. Na základě typu zvrstvení, vztahu k podloží a laterální omezenosti je možné těleso interpretovat jako hrubozrnný subakvatický kužel nebo deltu, vyplňující původně subglaciální kavitu (Brodzikowski - van Loon 1991; McCabe 1991; Clerc et al. 2012). Neprrítomnost topsetu ukazuje spíše na subakvatický kužel, ačkoliv svrchní část výplně, i s př́ípadným topsetem mohla být odstraněna erozí během následných ledovcových i postglaciálních procesů. Podle radargramů dosahuje výplň kavity mocnosti $\sim 400 \mathrm{~cm}$ a laterálního rozsahu min. $30 \times 30 \mathrm{~m}$. Stratigrafické pořadí jednotek v rámci foresetu je následující: 2c-2d-2e-2a-2b. Jednotka 2c byla uložena vysokohustotními turbiditními proudy (Lowe 1982). Jednotka 2d zaznamenává stř́idání vysokohustotních turbiditních proudů (zvrstvené sedimenty) a podřízených úlomkotoků (tenké masivní polohy s velkými klasty). Jednotky 2e, 2a, 2 b byly uloženy jen subakvatickými úlomkotoky (Kostic et al. 2005). Individuální klasty mohly na svah kuželu (delty) padat i z odtávající báze ledovce, která tvořila strop kavity (Bennett et al. 2006). Velkoškálové ukloněné zvrstvení s sklony kolem $20^{\circ}$ vzniká i v subaerických terminoglaciálních kuželech, ale u těchto upadá paralelně se sklonem dnešního povrchu kuželu (např. Krzyszkowski 2002). V případě štachlovické lokality však neexistuje žádná shoda mezi průběhem povrchu dnešního terénu a úklonem zvrstvení. Subaerické terminoglaciální kužely mají lokálně omezený zdroj materiálu (relativně krátkou část okraje ledovce), od kterého paprsčitě progradují směrem dopředu (Krzyszkowski - Zieliński 2002). Orientace zvrstvení a dlouhých plochých klastů výplně kavity však ukazují na progradaci k SV v počáteční fázi, která se postupně měnila na východní, jihovýchodní až se nakonec stočila k J (obr. 4c). Směry př́nosu materiálu se tedy měnily $\mathrm{v}$ půlkruhu a zdroje materiálu depocentrum obklopovaly. Generelně severovýchodní přirůstání foresetu dokazují i georadarové profily, kdy se na řezu P7 uklánějí šikmé reflexy $\mathrm{k} \mathrm{V}$ a na řezu P8 k S (obr. 4a). Podle faciálního vývoje a trendu ve směru progradace byla kavita zpočátku vyplňována od JZ subglaciálním tokem. Později, jak se zintenzivňovalo bazální odtávání ledovce, byla kavita vyplněna úlomkotoky od $\mathrm{Z}$ a S. V samotném závěru mohlo dokonce nastat zborcení ledovcového stropu kavity a rychlé zaplnění zbylého prostoru subaerickými úlomkotoky, podobajícími se supraglaciální facii chaotických balvanitých štěrků Eylese - Clarka (1987). V závěrečné fázi se kavita mohla podobat některým moderním př́kladům z polytermálních ledovců (obr. 5). Subaerické terminoglaciální kužely nasedají plochou bází na rovný terén (Krzyszkowski - Zieliński 2002). Štachlovický foreset naopak jasně vyplňuje depresi ve členitém podloží (obr. 3b, 4a). Všechny popsané indicie a srovnání upřednostňují interpretaci foresetu jako kuželu (delty) vyplňujícího subglaciální kavitu. 
Člen 3 lze podle polohy v nadloží subglaciálně uloženého glacitektonitu a lepšího vytřídění interpretovat jako supraglaciální melt-out till (supraglaciální ablační till podle Brodzikowského - van Loona 1991). Přednostní orientace klastů naznačuje transport formou úlomkotoku. Materiál uvolněný z roztávajícího ledovce byl následně gravitačně resedimentován, což je pro supraglaciální prostředí charakteristické (Boulton 1972; Kjær - Krüger 2001; Ewertowski et al. 2011). Pohybující se materiál zapadal do štěrbin mezi bloky glacitektonitu a vyplňoval je jako krátké neptunické žíly (černé šipky na obrázku 3d, e).

Člen 4 představuje výplň koryta glacifluviálního toku. Výmolově se zahlubuje do výplně subglaciální kavity a zároveň bočně do supraglaciálního melt-out tillu. Na základě těchto stratigrafických vztahů se jedná o terminoglaciální tok. Genetickou nesouhlasnost s výplní kavity ukazuje i severozápadní orientace zvrstvení členu 4 (obr. 4c). Glacifluviální potoky a řeky běžně existují současně s ablačními morénami na mrtvém ledu nebo při okraji ledovce (Kłysz - Lindner 1982; Hambrey - Glasser 2012).

Hluboce zaříznutá báze členu 5 vznikla erozním působením intenzivního přívalu tavné vody. Následovalo rychlé uložení všech frakcí transportovaného materiálu z hyperkoncentrovaného proudu. Tyto znaky odpovídají subfacii P-3a proximálních částí terminoglaciálních kuželů podle Zielińského - van Loona (1999). Diamiktické polohy představují v proudu nedostatečně rozptýlený materiál erodovaných supraglaciálních tillů (Zieliński 1992). Radargram P8 zobrazuje značný laterální rozsah členu 5 (obr. 4a). Šedou šipkou označený reflex v radargramu P8 odpovídá bázi členu $5 \mathrm{v}$ profilu B. Subhorizontální a mírně ukloněné reflexy nad tímto reflexem $\mathrm{v}$ jižním úseku radargramu P8 nejspíš představují dílčí koryta nebo lavice. Na základě litologie, charakteru báze, pozici vůči výplni subglaciální kavity a laterálního rozsahu představuje člen 5 terminoglaciální výplavovou plošinu. Hluboký erozní zářez v profilu B nejspíš představuje okraj celé plošiny. Jemu odpovídající, šedou šipkou označený reflex v profilu P8 pak představuje hlavní erozní bázi celé plošiny. Podobné plošiny s divočícími kanály, $\mathrm{v}$ nichž je rozsáhle resedimentován materiál především supraglaciálních tillů dnes pravidelně existují v širokých pásmech ablačních morén při čelech polytermálních ledovců (Kłysz - Lindner 1982; Hambrey - Glasser 2012).

\section{Vývoj sedimentačního prostředí}

Nejstarším sedimentem na lokalitě je glacitektonit (člen 1). Vznikl v subglaciální zóně během postupu ledovce po náběžné (severovýchodní) straně skalní elevace. Uspořádání granitoidních bloků naznačuje pohyb ledovce od východu k západu v profilu A (obr. 3e), a od severu k jihu v profilu D (obr. 3f). Lokální směr pohybu ledovce lze tedy vyvozovat ve směru SV-JZ.

Po překlenutí elevace ledovcem vznikla za elevací dutina (kavita). Její prostor byl ohraničen strmou, vůči postupu ledovce odvrácenou stranou elevace, povrchem preglaciálního podloží za elevací a bází ledovce. Vznik kavit za překážkami překonávanými ledovci je v subglaci-

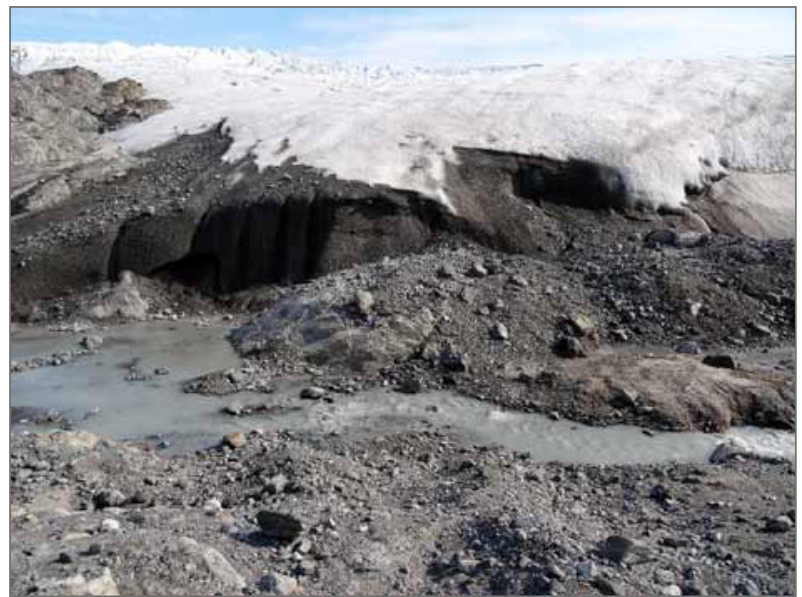

Obr. 6: Supraglaciální melt-out tilly derivované z bazální zóny ledovce bohaté na detrit. Tilly se ukládají na členitý skalní podklad před čelem ledovce. Moderní ekvivalent k členu 3. Ledovec Nordenkiöldbreen, Svalbard.

Fig. 6: Supraglacial melt-out till derived from basal debris-rich part of glacier. Tills are deposited on rugged bedrock topography close to the glacier front. Modern analogue to member 3. The Nordenskiöldbreen glacier, Svalbard.

álním prostř̌edí běžným jevem (Brodzikowski - van Loon 1991; Clerc et al. 2012).

Prostor v kavitě vyplnilo podledovcové jezero, do kterého vstupoval subakvatický kužel nebo hrubozrnná delta. Změna depozičního stylu od vysokohustotních turbiditů k úlomkotokům během progradace foresetu patrně odráží stále intenzivnější odtávání bazální zóny ledovce bohaté na klastický materiál (basal debris-rich ice, např̀ Benn - Evans 2010). Převaha hrubších frakcí byla způsobena jejich dominancí v subglaciálně transportovaném materiálu (i diamiktické části glacitektonitu jsou štěrkem bohaté) a transportem jemných frakcí až na dno kavity, které nebylo v profilech odkryto. Postupující progradací foresetu se volný prostor stále zmenšoval. V samotném závěru vyplňování kavity byly úlomkotoky náhle zastaveny o svislou stěnu skalní elevace, což vedlo k náhlému uložení všech frakcí. Proto se podél stěny vyskytují diamiktony. Opakovaným zastavováním úlomkotoků nastala amalgamace jejich uloženin. Šikmé zvrstvení se stalo nezřetelným a bezprostředně před elevací jej nahradila masivní textura. Diamiktony s hojnými velkými klasty podél stěny elevace však mohly vzniknout i náhlou subaerickou sedimentací po zborcení stropu kavity, oslabenému neustálým táním ledu.

Po vyplnění kavity proběhla degradace zbylého ledovce, jejímž sedimentárním záznamem jsou terminoglaciální a supraglaciální členy 3, 4, 5. Stratigrafický vztah mezi členy 3 a 4 je jasně odkryt v profilu A. Ovšem vztah těchto členů $\mathrm{k}$ členu 5 nelze přímo doložit. Jelikož jsou členy 3 a 4 situovány morfologicky poněkud níže než člen 5 (obr. 2), lze předpokládat toto stratigrafické pořadí: člen 5, člen 3, člen 4. Do reliéfu zarovnaného sedimentární výplní podledovcové kavity se erozně zařízl vysokoenergetický terminoglaciální tok, který následně rychle ukládal své špatně vytříděné sedimenty (člen 5). Okraj výplavové plošiny byl patrně ohraničen ledovcem, který zabránil rozšíření 
divočících koryt přes celou výplň kavity. Na druhou stranu nebyla plošina nijak omezena skalní elevací, na rozdíl od ostatních členů sedimentární akumulace. Neprůběžné diamiktické polohy vznikly sklouznutím materiálu do řečiště z povrchu ledovce nebo $\mathrm{z}$ ablační morény s ledovým jádrem. Vyplněním koryt přestala být tato část plošiny aktivní, čímž ustala říční hloubková i laterální eroze výplně subglaciální kavity.

Zánik ledovce pokračoval. Na temeni a pozvolném severovýchodním svahu elevace odtával ledovec od povrchu a místy rovněž od báze, až nakonec podlehla ablaci i bazální zóna ledovce bohatá na detrit. Voda pronikající pod ledovec místy rozplavovala mezihmotu glacitektonitu a největší prostory mezi granitoidními bloky vyplňovala vytř́iděnými zvrstvenými sedimenty. Účinky tavné vody mohly vést $k$ částečné lokální degradaci původní struktury glacitektonitu, ačkoliv uspořádání bloků v glacitektonitu nenaznačuje významnější resedimentaci. Uvolněním klastik z bazální zóny ledovce vznikl supraglaciální melt-out till. Ten byl následně nebo už během ablace gravitačně resedimentován po svažitém okraji zbytkového ledovce nebo povrchu elevace. Zařazení k supraglaciálnímu melt-out tillu umožňuje skutečnost, že bazální led odtává od povrchu i od báze ledovce současně, vytátý materiál se smíchá a může být pak společně dále gravitačně, prrípadně fluviálně, resedimentován (obr. 6). Vzniklý úlomkotok (člen 3) pokryl glacitektonit a natekl do štěrbin mezi granitoidními bloky, čímž vznikly neptunické žíly. Povrchová zóna glacitektonitu byla působením přes ni tekoucího úlomkotoku mobilizována a menší granitoidní klasty zapadaly do štěrbin spolu s materiálem úlomkotoku (bílá šipka v obrázku 3e). Úlomkotok také mělce erodoval odtržence písku v glacitektonitu (obr. 3d).

Po těchto procesech byla skalní elevace ze západní strany obklopena výplní kavity a temeno, severovýchodní svah elevace a glacitektonit byly pokryty supraglaciálním tillem. Ledovcové čelo se však nacházelo v bezprostřední blízkosti, čemuž nasvědčuje pokračování vývoje ve znamení glacifluviální sedimentace. Povrch výplně kavity a k západu mírně upadající temeno elevace se staly dnem terminoglaciálního toku, který erodoval výplň kavity a větvil se mezi výstupky skalní elevace (člen 4). Vzhledem $\mathrm{k}$ velikosti koryta a jemnozrnnosti výplně se jednalo o slabý, mělký tok s nedostatečnou kapacitou k transportu hrubého materiálu.

Kromě glacitektonitu nenesou sedimenty štachlovické lokality žádné deformační struktury. Jejich absence naznačuje, že všechny členy mladší než glacitektonit vznikly při ústupu zalednění, kdy již nedocházelo k porušení sedimentů tlakem pohyblivého ledovcového ledu. $V$ deglaciační fázi narůstá množství subglaciální tavné vody a dochází ke zvětšování kavit na bázi ledovce, přičemž kavity se často tvoří právě kolem oblíků nebo drumlinů (Clerc et al. 2012). Subglaciální pozici glacitektonitu a výplně kavity jasně dokládá jejich vztah k preglaciálnímu reliéfu. Charakter subglaciálního sedimentačního prostředí štachlovické lokality indikuje teplý nebo polytermální režim na bázi pevninského ledovce (Eyles et al. 1983). Nepř́ítomnost kolapsových struktur v členech 4 a 5 i jejich zahloubení do subglaciálních a supraglaciálních členů přiřazuje oba členy spíše k terminoglaciální než supraglaciální pozici. Supraglaciální glacifluviální sedimenty bývají zahloubeny do ledovce. Po jeho roztátí se výplně koryt stanou konvexními tvary reliéfu, jejich okraje zkolabují a sedimentární záznam se zdeformuje (Livingstone et al. 2010). To je v porovnání s členy 4 a 5 zcela opačná situace.

\section{Složení a pưvod štěrkového materiálu}

Ve všech členech tvoří klasty stejné horninové typy, pocházející z hlavního hřebene Rychlebských hor (Skácelová 1994; Žáček 1995). Vidnavsko leží v oblasti, kde se před zásahem ledovce míchal klastický materiál aluviálních kuželů a řek z celého hlavního hřebene Rychleb (Hanáček 2014). Tyto sedimenty pak byly erodovány ledovcem. Kvưli materiálovému promíchání preglaciálních uloženin se v ledovcových sedimentech Vidnavska objevují horniny centrální až jihovýchodní části hlavního hřebene Rychleb (amfibolity, metagabra, svory) i sz. části hřebene (gierałtowská rula, grafitický kvarcit). Vzhledem k dominantní roli amfibolitů, doprovázených metagabry, lze za hlavní zdroj materiálu ledovcových sedimentů štachlovické lokality považovat preglaciální štěrky Vidnávky v severním sousedství lokality. Uvedená metabazika jsou velmi hojnou složkou i postglaciálních sedimentů Vidnávky (Žáček et al. 2004). Dalším významným zdrojem byly severněji ležící preglaciální fluviální sedimenty, které poskytly např̀. gierałtowskou rulu a grafitický kvarcit. Na původ klastů ve fluviálních sedimentech ukazuje i převládající suboválné zaoblení. Klasty šedobílých hornin granitoidního vzhledu mohou primárně pocházet $\mathrm{z}$ žulovského masivu (granit, granodiorit) i z hlavního hřebene Rychlebských hor (hrubozrnné partie gierałtowské a sněžnické ruly, leukokratní partie granodioritovo-tonalitové intruze ve staroměstkém krystaliniku, javornický granodiorit, Pouba et al. 1962; Müller et al. 2003). Klasty petrograficky odpovídající přímému skalnímu podloží ledovcových sedimentů byly zjištěny jen ve formě angulárních bloků v glacitektonitu.

Subglaciální sedimenty (člen 1 a spodní část jednotky 2 b) se od supra- a terminoglaciálních členů 3 a 5 odlišují v podílech klastů jednotlivých hornin (obr. 4d). V subglaciálních sedimentech jsou dominantními horninami amfibolity, doprovázené metagabry, zatímco ostatní složky jsou méně početné. Supra- a terminoglaciální sedimenty žádnou převažující komponentu neobsahují a všechny horniny jsou zastoupeny rovnoměrnějšími podíly. Zároveň roste podíl provenienčně distálních (nordických a polských) hornin, byt ne razantně. Svrchní část jednotky 2b má skladbu klastů na přechodu mezi oběma skupinami. V subglaciálních členech převládají klasty erodované ledovcem v přilehlém údolí Vidnávky. Materiál byl transportován jen krátce a záhy uložen na bázi ledovce. Supraa terminoglaciální sedimenty obsahují materiál z celého ledovcového tělesa, tedy včetně distálnějších komponent. Přechodný charakter svrchní části výplně kavity naznačuje smíchání materiálu z bazální i vnitřní části ledovce a tím i kombinaci procesů subglaciální a povrchové ablace. 


\section{Lokalita jako tvar reliéfu zaledněného území}

Velké deprese na povrchu granitoidní elevace nejspíš představují původní skalní mísy a drobné konkávní tvary mohou odpovídat odtokovým žlábkům. Povrch elevace má tedy zachovalou morfologii vzniklou před samotným zásahem ledovce. Je však možné, že by drobné deprese mohly představovat i příčné průřezy hrubými exaračními rýhami, takže by povrch elevace současně nesl morfologické tvary vzniklé chemickým a mechanickým zvětráváním a také ledovcovou exarací.

Podle vztahu preglaciální morfologie a ledovcových sedimentů představuje štachlovická lokalita drumlin, jehož jádro tvoří elevace skalního podloží pokrytá a obklopená ledovcovými sedimenty. V moderní klasifikaci drumlinů je lokalita nejblíže typu drumlinu tvořenému podložními horninami a na nich ležícími tilly (part bedrock/part till drumlin, Stokes et al. 2011). Na náběžné straně těchto drumlinů dochází $\mathrm{k}$ deformaci a brekciaci podloží postupujícím ledovcem a k zakomponování bloků podložních hornin do ledovcem transportovaného detritu (Meehan et al. 1997). Šikmo zvrstvené i masivní sedimenty vznikají na vi̊či ledovci odvrácené straně drumlinů nebo v širokých depresích zahloubených do podloží, které sloužily jako koryta subglaciálních tokủ (McCabe 1991). Formování drumlinů během postupové i ústupové fáze zalednění dokumentují sukcese subglaciálních lodgement- a melt-out tillů a supraglaciálních melt-out tillů $\mathrm{v}$ některých finských drumlinech (Aario - Peuraniemi 1992). Drumlinizační proces i vznik podledovcových kavit podmínily paleogeografické podmínky, kdy ledovec postupoval generelně od severu proti príkrému svahu Žulovské pahorkatiny. Typický drumlinový tvar se nevyvinul dokonale, protože lokalita před zaledněním nepředstavovala izolovaný vrchol, ale okraj pahorkatiny. Jižní svah preglaciálního reliéfu byl navíc pokryt deglaciačními sedimenty, čímž byla morfologie terénu zarovnána.

\section{Závěr}

Odkryv u Štachlovic dokumentuje úzký genetický vztah ledovcových sedimentů $\mathrm{k}$ členité morfologii preglaciálního podloží žulovského masivu. Pevninskýledovec se v tomto místě pohyboval od SV k JZ př̀s elevaci granitoidu. Na náběžné straně elevace vznikly glacitektonity, dokládající postupovou fázi zalednění. Ve směru postupu ledovce za elevací vznikla subglaciální kavita, ohraničená reliéfem podloží a bází ledovce. Kavita byla vyplňována hlavně během deglaciace foresetovým tělesem subakvatického kuželu nebo delty, v samotném závěru vyplňování možná i subaerickými úlomkotoky. Těsně před čelem ledovce pak přes výplň kavity proudil terminoglaciální tok. Roztáváním ledovce vznikl na povrchu elevace supraglaciální melt-out till. Mezi ablačními morénami a výstupky skalní elevace proudil slabý terminoglaciální potok. Klastický materiál se $\mathrm{v}$ rámci tělesa ledovce nejpravděpodobněji uvolňoval z bazálního ledu bohatého na detrit. Štěrkové klasty jsou složeny hlavně z ledovcově resedimentovaného materiálu preglaciálních řek v oblasti, zejména z Vidnávky. Subglaciální sedimenty jsou petrograficko-provenienčně monotónnější než supra- a terminoglaciální sedimenty. Celou lokalitu lze považovat za drumlin s jádrem tvořeným podložními horninami a na nich ležícími sedimenty (part bedrock/part till drumlin podle klasifikace Stokese et al. 2011). Je pravděpodobné, že obdobné drumliny se na severním, vůči postupujícímu ledovci exponovaném okraji Žulovské pahorkatiny tvořily mnohem častěji. Štachlovický odkryv představuje významnou lokalitu pro poznání průběhu pevninského zalednění na reliéfu žulovského masivu.

\section{Poděkování}

Autoři děkují recenzentu Danielu Šimíckovi z Katedry geologie Prírodovědeckéfakulty Univerzity Palackého v Olomouci a dále nezveřejnènému recenzentovi za prípomínky a návrhy, které zkvalitnily předkládaný príspèvek.

Literatura

Aario, R. - Peuraniemi, V. (1992): Glacial dispersal of till constituents in morainic landforms of different types. - Geomorphology, 6, 9-25.

Benn, D. I. - Evans, D. J. A (2010): Glaciers and glaciation - 802 s. Hodder Education. London. Second edition.

Bennett, M. R. - Huddart, D. - Waller, R. I. (2006): Diamict fans in subglacial water-filled cavities - a new glacial environment. - Quaternary Science Reviews, 25, 3050-3069.

Boulton, G. S. (1972): Modern Arctic glaciers as depositional models for former ice sheets. - Journal of the Geological Society of London, 128, 361-393.

Brodzikowski, K. - van Loon, A. J. (1991): Glacigenic Sediments. - 674 s. Elsevier. Amsterdam.

Cassidy, N. J. - Russell, A. J. - Marren, P. M. - Fay, H. - Knudssen, O. - Rushmer, E. L. - van Dijk, T. A. G. P. (2003): GPR derived architecture of November 1996 jokulhlaup deposits, Skeidararsandur, Iceland. - In: Bristow, C. S. - Jol, H. M. (eds): Ground Penetrating Radar in Sediments. 153-166, Geological Society, Special Publications, 211, London.

Clerc, S. - Buoncristiani, J.-F. - Guiraud, M. - Desaubliaux, G. - Portier, E. (2012): Depositional model in subglacial cavities, Killiney Bay, Ireland. Interactions between sedimentation, deformation and glacial dynamics. - Quaternary Science Reviews, 33, 142-164. 
Croot, D. G. - Sims, P. C. (1996): Early stages of till genesis: an example from Fanore, County Clare, Ireland. - Boreas, $25,37-46$.

Evans, D. J. A. - Phillips, E. R. - Hiemstra, J. F. - Auton, C. A. (2006): Subglacial till: Formation, sedimentary characteristics and classification. - Earth-Science Reviews, 78, 115-176.

Ewertowski, M. - Kasprzak, L. - Szuman, I. - Tomczyk, A. M. (2011): Controlled, ice-cored moraines: sediments and geomorphology. An example from Ragnarbreen, Svalbard. - Zeitschrift für Geomorphologie, 56, 53-74.

Eyles, N. - Clark, B. M. (1987): Coarse-grained sediment gravity flow facies in a large supraglacial lake. - Sedimentology, 34, $193-216$.

Eyles, N. - Eyles, C. H. - Miall, A. D. (1983): Lithofacies types and vertical profile models; an alternative approach to the description and environmental interpretation of glacial diamict and diamictite sequences. - Sedimentology, 30, 393-410.

Gába, Z. (1972): Souvková hlína ze Skorošic a směr pohybu pevninského ledovce. - Zprávy Vlastivědného ústavu v Olomouci, $155,23-28$.

Gába, Z. (1992): Profil ledovcovými uloženinami u Vidnavy ve Slezsku. - Časopis Slezského muzea (A), 41, 167-172.

Hambrey, M. J. - Glasser, N. F. (2012): Discriminating glacier thermal and dynamic regimes in the sedimentary record. - Sedimentary Geology, 251-252, 1-33.

Hanáček, M. (2014): Význam valounových analýz ledovcových sedimentů pro paleogeografické rekonstrukce pleistocenního kontinentálního zalednění Jesenicka. - Geologické výzkumy na Moravě a ve Slezsku, 21 (1-2), 17-24.

Hanáček, M. - Nývlt, D. - Nehyba, S. (2013): Písečník u Javorníku - drumlin se zachovalou sukcesí subglaciálních a supraglaciálních sedimentů. - Geologické výzkumy na Moravě a ve Slezsku, 20, 22-29.

Hanáček, M. - Skácelová, Z. - Nehyba, S. - Nývlt, D. (2015): Nová interpretace ledovcových sedimentů lokality Písečná u Jeseníku. - In: Nohálová, H. - Káňa, V. - Březina, J. (eds): 21. Kvartér 2015, Brno 27. 11. 2015, Sborník abstrakt, 17-19. Masarykova univerzita.

Kjær, K. H. - Krüger, J. (2001): The final phase of dead-ice moraine development: processes and sediment architecture, Kötlujökull, Iceland. - Sedimentology, 48, 935-952.

Kłysz, P. - Lindner, L. (1982): Evolution of the marginal zone and the forefield of the Bunge Glacier, Spitsbergen . - Acta Geologica Polonica, 32, 253-266.

Kostic, B. - Becht, A. - Aigner, T. (2005): 3-D sedimentary architecture of Quaternary gravel delta (SW-Germany): Implications for hydrostratigraphy. - Sedimentary Geology, 181, 143-171.

Krzyszkowski, D. (2002): Sedimentary successions in ice-marginal fans of the Late Saalian glaciation, southwestern Poland. Sedimentary Geology, 149, 93-109.

Krzyszkowski, D. - Zieliński, T. (2002): The Pleistocene end moraine fans: controls on their sedimentation and location. - Sedimentary Geology, 149, 73-92.

Livingstone, S. J. - Evans, D. J. A. - Cofaigh, C. Ó. - Hopkins, J. (2010): The Brampton kame belt and Pennine escarpment meltwater channel systém (Cumbria, UK): Morphology, sedimentology and formation. - Proceedings of the Geologists' Association, 121, 423-443.

Lowe, D. R. (1982): Sediment gravity flows: II. Depositional models with special reference to the deposits of high-density turbidity currents. - Journal of Sedimentary Petrology, 52, 279-297.

McCabe, A. M. (1991): The distribution and stratigraphy of drumlins in Ireland. - In: Ehlers, J. - Gibbard, P. L. - Rose, J. (eds): Glacial deposits in Great Britain and Ireland, 421-435, A.A. Balkema.

Meehan, R. T. - Warren, W. P. - Gallagher, C. J. D. (1997): The sedimentology of a Late Pleistocene drumlin near Kingscourt, Ireland. - Sedimentary Geology, 111, 91-105.

Müller, V. - Čurda, J. - Jinochová, J. - Majer, V. - Manová, M. - Sáňka, V. - Skácel, J. - Skácelová, D. - Večeřa, J. - Žáček, V. (2003): Vysvětlivky k souboru geologických a ekologických účelových map př́rodních zdrojů v měřítku $1: 50$ 000. Listy 04-43 Bílý Potok, 04-44 Javorník, 14-21 Travná, 14-22 Jeseník. - 80 s., Česká geologická služba.

Nývlt, D. - Engel, Z. - Tyráček, J. (2011): Pleistocene glaciations of Czechia. - In: Ehlers, J. - Gibbard, P. L. - Hughes, P. D. (eds): Quaternary Glaciations - Extent and Chronology Part IV - a closer look. Developments in Quaternary Science, 37-46, Elsevier.

Pecina, V. - Čurda, J. - Hanáček, M. - Kočandrle, J. - Nývlt, D. - Opletal, M. - Skácelová, D. - Skácelová, Z. - Večeřa, J. - Žáček, V. (2005): Základní geologická mapa České republiky 1 : 25 000, list 14-221 Žulová s Vysvětlivkami. - MS, Česká geologická služba.

Pouba, Z. - Dvořák, J. - Kužvart, M. - Mísař, Z. - Musilová, L. - Prosová, M. - Röhich, P. - Skácel, J. - Unzeitig, M. (1962): Vysvětlivky k přehledné geologické mapě ČSSR 1:200 000, list M-33-XVIII Jeseník. - 178 s., Ústřední ústav geologický.

Powers, M. C. (1953): A new roundness scale for sedimentary particles. - Journal of Sedimentary Petrology, 23, 117-119.

Prosová, M. (1981): Oscilační zóna kontinentálního ledovce. Jesenická oblast. - Acta Universitatis Carolinae, Geologica, 3, $265-294$.

Růžičková, E. - Růžička, M. - Zeman, A. - Kadlec, J. (2003): Kvarterní klastické sedimenty České republiky. Struktury a textury hlavních genetických typů - 92 s. Česká geologická služba. Praha.

Skácelová, D. (1994): Geologická mapa ČR 1 : 50 000, list 04-43 Bílý Potok. - Český geologický ústav.

Stokes, Ch. R. - Spagnolo, M. - Clark, Ch. D. (2011): The composition and internal structure of drumlins: Complexity, commonality, and implications for a unifying theory of their formation. - Earth-Science Reviews, 107, 398-422.

Zieliński, T. (1992): Moreny czołowe Polski północno-wschodniej - osady i warunki sedymentacji. - 95 s. Uniwersytet Śląski. Katowice.

Zieliński, T. - van Loon, A. J. (1999): Subaerial terminoglacial fans I: a semi-quantitative sedimentological analysis of the proximal environment. - Geologie en Mijnbouw, 77, 1-15.

Žáček, V. (1995): Geologická mapa ČR 1 : 50 000, list 14-22 Jeseník. - Český geologický ústav. Praha.

Žáček, V. - Čurda, J. - Kočandrle, J. - Nekovař́ik, Č. - Nývlt, D. - Pecina, V. - Skácelová, D. - Skácelová, Z. - Večeřa, J. (2004): Základní geologická mapa České republiky 1 : 25 000, list 14-222 Vidnava s Vysvětlivkami. - Česká geologická služba. Praha. 